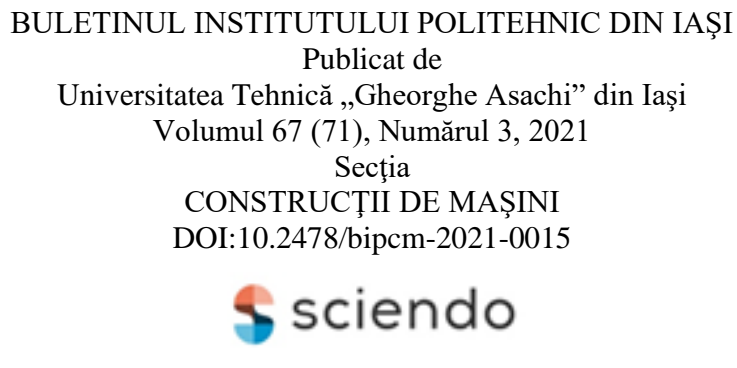

\title{
SOLUTIONS FOR REDUCING THE ENERGY CONSUMED BY THE AUTOMOTIVE HVAC SYSTEM
}

BY

\author{
AIDA MARIA VRANĂU ${ }^{1, *}$, CARMEN BUJOREANU ${ }^{1}$ and VASILE CAUNII ${ }^{2}$ \\ 1“Gheorghe Asachi” Technical University of Iaşi, \\ Faculty of Mechanical Engineering, Iaşi, Romania \\ ${ }^{2}$ S.C. Xtreme Chip S.R.L, Iaşi, Romania
}

Received: March 30, 2021

Accepted for publication: June 28, 2021

\begin{abstract}
The first cars with air conditioning appeared in the early 1940s. Then, 1500 Packard cars received an air conditioning system developed by Nash. In the 60 s about $20 \%$ of the total production of cars had air conditioning system. Nowadays car manufacturers consider air conditioning as a standard option and try various solutions to increase thermal comfort and road safety. The air conditioning system in the current configurations is a big energy consumer system. All changes made to reduce the energy consumed will take into account temperature, humidity level, vibration and noise so that human safety and comfort are not affected. The purpose of this paper is to review the ways to reduce the energy consumed by the air conditioning system of cars and their importance.
\end{abstract}

Keywords: air conditioning; energy; comfort; car power; fuel consumption.

\section{Introduction}

The development of air conditioning systems for the automotive field began in 1930. Then, the General Motors Research Laboratory needs a vapour

${ }^{*}$ Corresponding author; e-mail: andavran16@gmail.com

(C) 2021 Aida Maria Vranău et al.

This is an open access article licensed under the Creative Commons Attribution-NonCommercialNoDerivatives 4.0 International License (CC BY-NC-ND 4.0). 
compression system with a refrigerant. By World War II, about 3,000 American cars were equipped with air conditioning. The system was installed in special luxury cars. During the complete war systems they were taught to be mounted on military vehicles (Bhatti, 2008).

In Europe, about $90 \%$ of cars are equipped with Original Equipment Manufacturers passenger compartment filters (Reinhardt, 2005).

The abbreviation HVAC comes from Heating Ventilation Air Conditioning. The heating process takes place at a comfortable thermal level in the house, car or office. Ventilation is a process by which the air in the car is evacuated and replaced with outside air, filtered, heated or cooled, depending on the temperature outside. The air conditioning is supplied by cooling the air recirculated from the inside with the help of a heat radiator charged with refrigerant (All4ventilation, 2018).

The ventilation and air conditioning system is an almost indispensable system nowadays (E-automobile, 2015). The major car manufacturers standard equip the car with air conditioning system in several areas to increase the comfort of the passengers. Also, the HVAC system can create some inconvenience to the driver in case of problems in operation.

An important role in the proper functioning of the air conditioning system is the pollen filter that is mounted on the car. The pollen filter is created from filter paper and other layers with different functions. At this moment the most used filters in the automotive industry are those with activated carbon layer. These filters capture the small particles (dust, pollen), but due to the properties of the activated carbon they stop and the odour enters the interior (Vranău and Bujoreanu, 2019).

Students, researchers, teachers and car enthusiasts are studying different methods to maximize the level of comfort in the car. After the development of the high efficiency filters, tests were carried out on various machines to see how the air conditioning systems behave under similar road conditions.

All the states of the world are trying to reduce the level of air pollution, and for this they have imposed strict rules, but also rigorous checks for their compliance (Actiunea UE, 2006). In Romania, the air quality is monitored by 148 automatic stations and 11 mobile stations (Calitate aer). One of the sources of air pollution is high fuel consumption. The HVAC system is an energy consumer, thus contributing to the increase in fuel consumption and thus to a greater amount of harmful gases entering the atmosphere.

In general, the air conditioning system is composed of compressor, condenser and vaporizer. The component that practically generates the increase in fuel consumption is the compressor. It is put into operation by means of a drive belt through the drive shaft. For this reason, the engine has to bear the extra load, and this is done with power consumption (Promotor, 2017). 


\section{Human Thermal Comfort and Power Consumption of the HVAC System}

The notion of thermal comfort is a relatively subjective one because it depends on many psychological factors and human nature. For this reason, it is very difficult for the car manufacturer to reach the implementation of a ventilation and air conditioning system capable of satisfying all the customer's needs.

The thermal comfort factors are divided into different categories:

a) physical factors:

- indoor air temperature;

- the relative humidity of the indoor air;

- indoor air speed.

b) factors related to the accommodation capacity of the human body for maintaining the thermal balance:

- heat production;

- heat transferred;

- thermoregulation;

- thermal resistance of clothing;

- the influence of the clothes in order to evaporate.

The thermal balance of the human body is influenced by the heat produced and the heat yielded by the body. Both the heat yielded and the heat produced depend on the factors listed above. The feeling of thermal comfort is a conscious state that expresses gratitude to the existing thermal environment. The evaluation is carried out using the subjective comfort scale with seven levels: +3 (very hot); +2 (warm); +1 (slightly warm); 0 (neutral); -1 (cooling); 2 (cold); -3 (cold) (Notiuni de termofiziologie, 2017).

In 1939, the Packard cars with air conditioning system developed by Nash Motors were first equipped (Wikipedia, 2019). At that time the two main functions that such a system had to fulfil were to cool the indoor air and to dehumidify it.

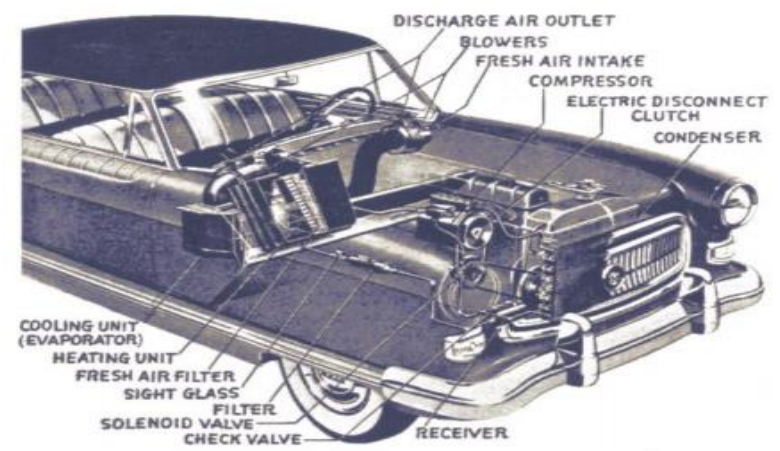

Fig. 1 - Nash Motors Weather Eye (Bhatti, 2008). 
In a study conducted by the Society of Automotive Engineers of the USA it was concluded that in the case of a journey with air conditioning started the fuel consumption increases by about 10 percent. For the test they used a field car and a sedan car for several hours under different conditions. Following this experiment it was found that, in the SUV, the consumption increased by $8 \%$ and in the sedan by almost $20 \%$. Experts in the field also said that driving with open windows affects fuel consumption as follows:

- for speeds over $64 \mathrm{~km} / \mathrm{h}$ it is recommended to use the heating, ventilation and air conditioning system;

- for lower speeds it is recommended to open the windows of cars.

As described above, the operation of the HVAC system takes place with energy consumption. The factors that influence the increase of the energy and implicitly an increase of the fuel consumption are:

- the cylindrical capacity of the engine;

- the type of supply;

- the fuel used.

A study by Emissions Analytics in Los Angeles is trying to highlight the differences depending on the type of monitoring. For this work, hundred cars with diesel engines, petrol and hybrids were used. The tests were performed both in urban mode and on the highway, on an established route, and in the end the fuel consumption was compared with the air conditioning on and off.

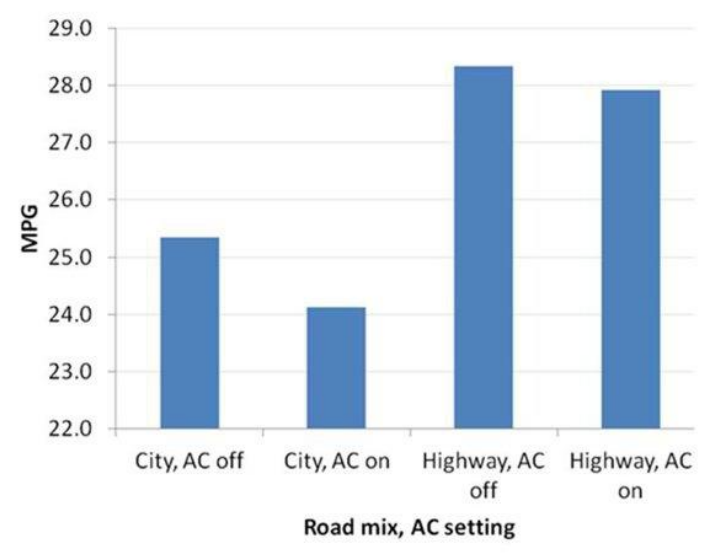

Fig. 2 - The influence of AC on fuel consumption (Promotor, 2017).

In Fig. 2, MPG means miles traveled with a gallon of fuel $(1 \mathrm{mi}=$ $1.609344 \mathrm{~km}$; 1US gal $=3.785412 \mathrm{l}$ ).

Fig. 2 shows how the fuel consumption is higher during the use of the air conditioning system in the city.

In the table below you can see the data collected from the tests for each type of engine: 
Table 1

Increased Fuel Consumption

\begin{tabular}{|c|c|c|c|}
\hline Average reduction in MPG & Combined & City & Highway \\
\hline \hline Diesel & $4.6 \%$ & $6.3 \%$ & $3.3 \%$ \\
\hline Gasoline & $3.8 \%$ & $5.1 \%$ & $2.7 \%$ \\
\hline Hybrid & $6.1 \%$ & $9.3 \%$ & $2.8 \%$ \\
\hline
\end{tabular}

The results show that both diesel engines and hybrid cars are affected by the use of the air conditioning system (Promotor, 2017).

In 1973, the oil crisis took place, and then the car manufacturers were forced to find new automotive solutions in order to replace the high-capacity engines with high fuel consumption with smaller, more efficient cylindrical engines lower fuel consumption (Caunii, 2015).

Due to the rules in force regarding polluting emissions, cars must have lower fuel consumption. This is achieved by thinking of intelligent systems with low energy consumption. These systems should not in any way affect the safety and comfort of passengers. Normally, an electric cooling fan with the blower of a middle-class car consumes about $500 \mathrm{~W}$.

Another important point to make the energy consumption of the HVAC system more efficient is to determine the degree of occupancy of the cars. A study from 2010 shows that in $61 \%$ of cases in the car there is only one person and in only $4 \%$ of situations the driver is accompanied by 3 passengers.

One of the simplest methods of reducing the consumed energy of the HVAC system is its proper maintain and use the type of cooling agent recommended by the manufacturer.

If it is taken into account that in most car trips, the driver is only, a simple method of reducing the energy consumed by the compressor is cooling only the occupied place.

This can be done by detecting the place occupied by the sensors of the impact safety system (airbags) or by mounting additional sensors.

\section{Conclusions}

The reduction of the energy consumed by the ventilation and air conditioning systems represents a method of reducing the fuel consumption and implicitly of the pollution.

Even though the use of the recirculation function may reduce the energy required to operate the compressor, we must take into account that a high level of carbon dioxide in the passenger compartment reduces the driver's ability to be concentrated.

The energy used unnecessarily leads to a decrease in engine power, which in the case of low power cars is a real disadvantage. For the following works I propose to collect data after replacing the large fan with other smaller fans. 


\section{REFERENCES}

Bhatti M.S., The Evolution of Automotive Air Conditioning - Riding in Comfort Part II ASHRAE Journal (HVAC\&R Nation) 44-50, 2008.

Caunii V., Teza doctorat: Studiu privind îmbunătățirea confortului termic de către instalațiile de climatizare pentru autoturisme, Conducător doctorat: prof. Univ. dr. ing. Dumitrașcu Gheorghe, 2015.

Reinhardt H., Automotive Trends: Cabin Air Filter Demands, Cover Story (Filtration + Separation), 2005.

Vranău A.M., Bujoreanu C., Study on Reducing Pollutant Gases and Particulate Content Inside the Passenger Car, 2019 IOP Conf. Ser.: Mater. Sci. Eng. 591 012033, 2019.

Wikipedia, Weather Eye http://en.wikipedia.org/wiki/Weather_Eye, 2019.

www.calitateaer.ro - Calitatea aerului în România.

** Acţiunea Uniunii Europene în vederea reducerii poluării aerului de către automobile, Bruxelles, 2006.

** All4ventilation, Ce înseamnă HVAC şi care este obiectivul sistemului, all4ventilation.ro/blog/ce-inseamna-HVAC-si-care-este-obiectivul-sistemului, 2018.

** E-automobile, Sistemul de aer condiţionat auto, http://www.e-automobile.ro/categoriemotor/20-general/154-sistem-aer-conditionat-auto-ac.html, 2015.

* * Noţiuni de termofiziologie, Confortul clădirilor, http://retele.elth.ucv.ro/Dinu\%20 Radu\%20Cristian/Instalatii\%20in\%20contructii/Curs\%201\%20-\%20Confortul \%20cladirilor.pdf, 2017.

* * Promotor, Cât de mult creşte consumul maşinii dacă foloseşti aerul condiţionat, 2017.

\section{SOLUT,II CONSTRUCTIVE PENTRU REDUCEREA ENERGIEI CONSUMATE DE SISTEMUL HVAC AUTO}

(Rezumat)

Primele mașini cu aer condiționat au apărut la începutul anilor '40. Apoi, 1500 de mașini Packard au primit un sistem de climatizare dezvoltat de Nash. În anii 60 , aproximativ $20 \%$ din producția totală de autoturisme era echipată cu sistem de aer condiționat. În prezent, producătorii de automobile consideră aerul condiționat ca o opțiune standard și încearcă diverse soluții pentru a crește confortul termic și siguranța rutieră. Sistemul de aer condiționat în configuraţiile actuale este un sistem care generează un consum mare de energie. Toate modificările aduse sistemului pentru a reduce energia consumată trebuie să țină cont de temperatură, nivelul de umiditate, vibrații și zgomot, astfel încât siguranța și confortul uman să nu fie afectate. Scopul acestei lucrări este de a trece în revistă modalitățile de reducere a energiei consumate de sistemul de climatizare a mașinilor și importanța acestora. 